\title{
ENVIRONMENTAL EFFECTS ON WOMEN-LED SMES IN ASIA: FROM INSTITUTIONAL PERSPECTIVE
}

\author{
KUMUDINEI DISSANAYAKE \\ University of Colombo, Sri Lanka \\ k_dis@hotmail.com
}

\begin{abstract}
Small and Medium-scale Enterprises (SMEs) led by women play a pivotal role in the developing economies. Nonetheless, extant research evince that Asian women-led SMEs and/or women entrepreneurs are still not performing up to their full potential. A range of factors, including institutional environmental forces, play a key role in impeding or expediting the success of women-led SMEs all over the globe. However, Asia shows a unique case due to its inherent socio-cultural, politico-legal and economic conditions those directly affecting the women, their career, and the business environment which are different to the other parts of the globe. Consequently, the macro environmental circumstances those affecting women-led SMEs in the Asian region deserve special scholarly attention. Despite the attempts to unveil institutional influences on SMEs in general, there is a dearth of studies those specifically examined the effects of institutional environment on women-led SMEs. Drawing from the institutional theory, and referring to the existing literature, this study examines the regulatory, cognitive, and normative effects of institutional environment on womenled SMEs. This is a conceptual paper which abstracts a coherent picture of three-fold institutional dimensions activated in the Asia and their effects on women's business. The implications are drawn for policy makers and future researchers.
\end{abstract}

Keywords: Asia, Entrepreneurship, Institutional environment, Regulatory, Cognitive, Normative, SMEs, Women

\section{Introduction}

The Asia and the Pacific region contain some of the world's most powerful economies and two-thirds of its poorest people. Rich in political, cultural and other forms of diversity, it faces common challenges from stark socioeconomic disparities, including those linked to gender (UNWOMEN, 2014). Further, UN estimates reveal that over half of Asia's population is women, and they could help the region grow by an additional $\$ 89$ billion annually (Weekly Insight and Analysis in Asia, 2013). Especially, in developing economies, women`s involvement in economic activities 
through Small and Medium-scale Enterprises (SMEs) has been enormous, despite their invisibility in the reports in numbers or values. Thus, the projected contribution of women to the development in the Asian region should not be undermined.

The extant research finds that Asian women-led SMEs and/or women entrepreneurs are still not performing up to their full potential. This fact is well proven with the finding that majority of women businesses in the Asia are based in the rural, traditional, or informal sector (IFC, 2011; Senguptha, Datta \& Momdal, 2013; World Bank, 2012) or remain as home-based businesses. They remain as microenterprises or small business (Bardasi, Sabarwal \& Terrell, 2011; Krishnan \& Kamalanabhan, 2013) in the longer-term or until (premature) death, thus rarely showing growth potential. Despite the existing potential, there are very few women who are choosing entrepreneurship as a career (Sinha, 2003).

This slow-growing nature of women-led SMEs is not visible only in Asia but has been the reality in some other countries. Previous studies have examined the factors leading to low performances of women-led SMEs or women entrepreneurship. Accordingly, the effect of demographic factors, individual motivation, experiences and availability of resources on the business performance and/or success of women entrepreneurs (e.g., Bennett \& Dann, 2000; Birley, 1989; Ekpe, Razak \& Mat, 2013; Lee \& Stearns, 2012), lack of micro-finance services, societal discriminations and lack of government's support (Ekpe, Razak, \& Mat, 2013), women's perception of environment (Kolvereid, Shane \& Westhead, 1993) have been found as the antecedents of their poor performances. As evidenced, the existing literature revolves around barriers against, or problems encountered by women entrepreneurs as seen from individual perspectives.

However, Asia stands to be a unique case due to its inherent socio-cultural, politicolegal and economic conditions which are directly affecting the women, their career, as well as its business environment (IFC, 2011; World Bank, 2014). The activators of the programs for economic development through women empowerment, equal employment, and disparity reduction (Wickremasinghe, 2011) in Asia undoubtedly need a complete knowledge of the uniqueness of Asian institutional environment. Thus, the macro environmental circumstances those affects women-led SMEs in the Asian region deserve special scholarly attention. The donor agencies, global development aid authorities, and even regional and local policy makers need to be cognizant of the unique institutions enacted in this region, in order to develop more realistic development plans for women-led SMEs. 
The existing regulatory forces, knowledge and skill base, and changing cultural and normative dimensions of the society play a pivotal role in impeding or expediting the success of SMEs in developing economies. Focusing on Asian economies', Powell (2007) reports that institutional environment plays a key role in directing entrepreneurship towards productive activities (p. 89). Institutional perspective, which covers broadly the macro environmental conditions of a country, specifically enables the investigation of environmental desirability for SMEs through regulatory, cognitive, and normative dimensions of a society (DiMaggio \& Powell, 1983; Scott, 1995).

Despite the research efforts to unveil the institutional influence on SMEs in general (e.g., Liu, Yang, \& Zang, 2012; Manolova, Eunni, \& Gyoshev, 2008; Roxas \& Coetzer, 2012; Zhu, Wittmann, \& Peng, 2012), there is a dearth of studies those examined the effects of institutional environment on women's business. Seemingly, the use of institutional perspective for investigating the environmental impact on women-led SMEs is rare to find. Nonetheless, the apex level decision-making bodies, including government authorities, can be immensely benefited with a macro level portrait of the effects of countries' institutional environment, especially for making policies towards women empowerment and facilitating women in business. Acknowledging this gap of knowledge in the context of developing economies in the Asian region, the present study aims to elaborate the institutional environmental effects on women-led SMEs in the Asia.

Drawing from the institutional theory, the present study examines the institutional environmental forces those affecting the women-led SMEs. Thus, this is a conceptual paper which discusses diverse institutional dimensions and their effect on women-led SMEs. Hereby I define 'women- led SMEs' as 'Small or medium-scale enterprises where the major operational and management decisions are made by one woman'. Moreover, individually-owned small and medium-scale enterprises are initiated and driven by individual entrepreneurial motives. Thus, this paper simultaneously discusses previous research findings related to women entrepreneurship', and interchangeably uses the term women entrepreneurs' and women SME holders ' in its presentation.

The structure of the paper is as follows. The next section presents an overview of the institutional environment while explicating the meaning of institutions and institutional environmental dimensions as used in this study. Followed by a summary of the research findings to evidence the distinct institutions enforced on entrepreneurship and SMEs, next, it presents diverse institutions affecting SMEs in 
developing economies. Built on this knowledge, the third section discusses the effect of institutional environment on women-led SMEs in the Asia in line with the regulatory, cognitive and normative dimensions. In the latter part of this paper, it identifies certain characteristics inherent in the women-led SMEs in the Asia. Summing up these findings in a coherent figure, finally, it concludes with highlights of the implications and directions for further research.

\section{Institutional Environment and its Dimensions}

Institutions are widely diffused rules, norms, and practices in a society. The institutional framework of a particular society is established on the rules, standards, norms, and practices those stemming from the fundamental political-legal, sociocultural and technological underpinnings of that society (North, 1990; North 1991). Institutions so established become the taken for granted realities (Berger \& Luckman, 1966) of the society, and subsequently affect the individual and organizational behavior thus creating psychic prisons (Morgan, 1998) from which people and organizations cannot be free for actions. However, institutions, the underlying rules of the game, provide structure to everyday life by guiding human interaction (North, 1991).

Institutional environment has been seen through three dimensions: regulatory, normative and cognitive (Scott, 1995), and previous research witnesses its use in entrepreneurship (Manolova, Eunni, \& Gyoshev, 2008; Roxas \& Coetzer, 2012; Tang \& Tang, 2012) and small firms (Urban, 2013). Institutional environment composites the structure of rules and regulations of the society, set of norms, values and unwritten codes of conduct in the society, and the human cognition on certain practices of the society (Roxas \& Coetzer, 2012; Scott, 1995). As such, the regulatory dimension of the institutional environment is broadly identified with formally codified, enacted and enforced structure of laws in a community, society, or nation (which may promote certain types of behavior and restrict others). Normative dimension of the society is recognized with social norms, values, beliefs and assumptions (that are socially shared and direct behavior through a web of social obligations and expectations). Further, cognitive dimension of the institutional environment is cognizant with the common framework of meaning or axiomatic beliefs that provide the templates and scripts for action (that are socially mediated constructions) (Roxas \& Coetzer, 2012; Scott, 1995). 


\section{Institutions Enforced on Entrepreneurship and SMES: A Review}

There have been numerous scholarly attempts to examine the effects of institutional environment on entrepreneurship or SMEs in the globe. Accordingly, the existing literature reveals a set of distinct institutions those enforced on entrepreneurship or SMEs. A summary of results derived in a review of such literature is presented on Table 1 below.

Table 1: Distinct Institutions Enforced on Entrepreneurship

\begin{tabular}{|c|c|}
\hline Institutions & Author \& Year \\
\hline \multicolumn{2}{|l|}{ Regulatory Dimension } \\
\hline Market economies & Smallbone \& Welter (2001) \\
\hline Policy context & Collins (2003) \\
\hline $\begin{array}{l}\text { Incentives, information, access and facilitation } \\
\text { (institutional support) }\end{array}$ & Ssewamala \& Sherraden (2004) \\
\hline $\begin{array}{l}\text { Regulatory and legal environment, business supports, } \\
\text { networks and associations }\end{array}$ & Stevenson \& St-Onge (2005) \\
\hline External forces & Davidsson, Hunter \& Klofsten (2006) \\
\hline Economic freedom & Powell (2007) \\
\hline Tax and welfare provisions & Aidis, Estrin, \& Mickiewicz (2010) \\
\hline $\begin{array}{l}\text { State sector, rule of law, regulations and policies } \\
\text { determined by the government }\end{array}$ & Estrin \&Mickiewicz (2011) \\
\hline Regulatory forces, legal environment & IFC (2011) \\
\hline Institutional and regulative logic & Griffy-Brown (2011) \\
\hline Business regulations, trade barriers, property rights & Beyer \& Fening (2012) \\
\hline Economy and politics & Eroglu (2012) \\
\hline For-profit and not-for-profit institutions & Katre \& Salipante (2012) \\
\hline Financial system & Clercq, Lim \& Oh (2013) \\
\hline Public policy & Edoho (2016) \\
\hline Economic and political institutions & Autio \& Fu (2015) \\
\hline \multicolumn{2}{|l|}{ Cognitive Dimension } \\
\hline Training and education & Bhardwaj (2004) \\
\hline Training and development & Stevenson \& St-Onge (2005) \\
\hline Technology & ICRW (2010) \\
\hline Role of technology & Griffy-Brown (2011) \\
\hline Educational system & Kantor (2012) \\
\hline Education system & World Bank (2012) \\
\hline Educational system & Clercq, Lim \& Oh (2013) \\
\hline Supportive systems (education) & Debroux (2013) \\
\hline Supportive systems (training) & Gupta (2013) \\
\hline Networking relationships & Omwenga, Mukulu \& Kanali (2013) \\
\hline Human capital acquisition, education & Jayawarna \& Jones (2014) \\
\hline \multicolumn{2}{|l|}{ Normative Dimension } \\
\hline Culture & Redding (1986) \\
\hline National culture, social system & Birley (1989) \\
\hline National culture & Steensma, Marino, Weaver \& Dickson(2000) \\
\hline Family system & Singh, Reynolds \& Muhammad (2001) \\
\hline Cultural tendencies and societal attitudes & Manolova, Eunni \& Gyoshev (2008) \\
\hline Gender-based occupational segregation & Kyrö (2009) \\
\hline Cultural environment & IFC (2011) \\
\hline
\end{tabular}


Societal attitudes

Social institutions: family, education, religion

Cultural dimension

Trust and cultural values

National culture

Societal perceptions

Cultural capital

Socially-supportive culture

Social, cultural, political system of the country

Country institutional profile (regulatory, cognitive \& Parboteeah, Hoegl, \& Cullen (2008)

Normative)

The above findings help to understand of the effects of institutional environment on SMEs.

The regulatory environment of a country is formed through the functions of its economic, political and legal institutions. Thus, the state sector itself, including the policy context, financial system, rule of law and regulations create the regulatory environment. Accordingly, the economic freedom, incentives, taxes and welfare provisions, trade barriers, and property rights will directly affect the functioning of SMEs.

The cognitive dimension of the institutional environment is basically molded through the human capital development efforts of the country. Thus, educational system, technology, and supportive systems for training and development and networking broadly affect the SME sector in a country.

As indicated in the above review, the national culture and the cultural tendencies and the social system sets grounds for the normative environment of a country. Thus, family systems, societal perceptions, attitudes, and social norms create an environment in which the entire society develops its expectations and view of the world accordingly. Behavioral tendencies, role expectations, gender-based occupational segregations at the business are resultant to the normative dimension of the institutional environment. Thus, business start-up decisions, ownership, the degree of involvement, the devotion of time, mobility and expansion decisions of SMEs can be strongly influenced by the normative environment.

\section{Institutional Environments in Developing Economies}

Developing economies experience underdeveloped institutional environments (Smallbone \& Welter, 2011). The effects of regulatory, cognitive and normative dimensions on the entrepreneurship and SMEs have been found in the past research. Table 2 below depicts a summary of research findings of the institutions affecting entrepreneurship and SMEs in developing economies particularly. 


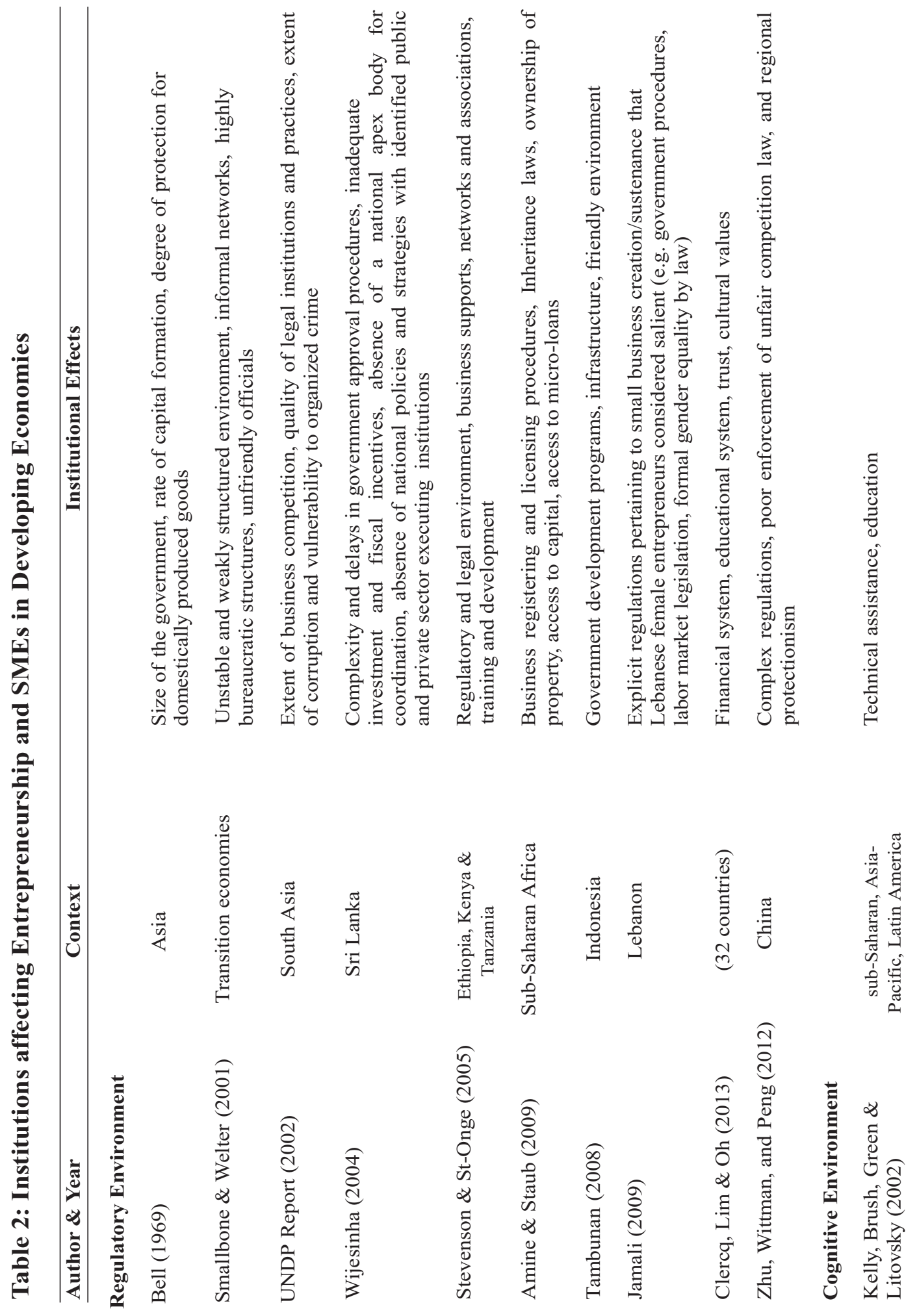

Journal of Business Studies, 5 (1)

$-07-$ 

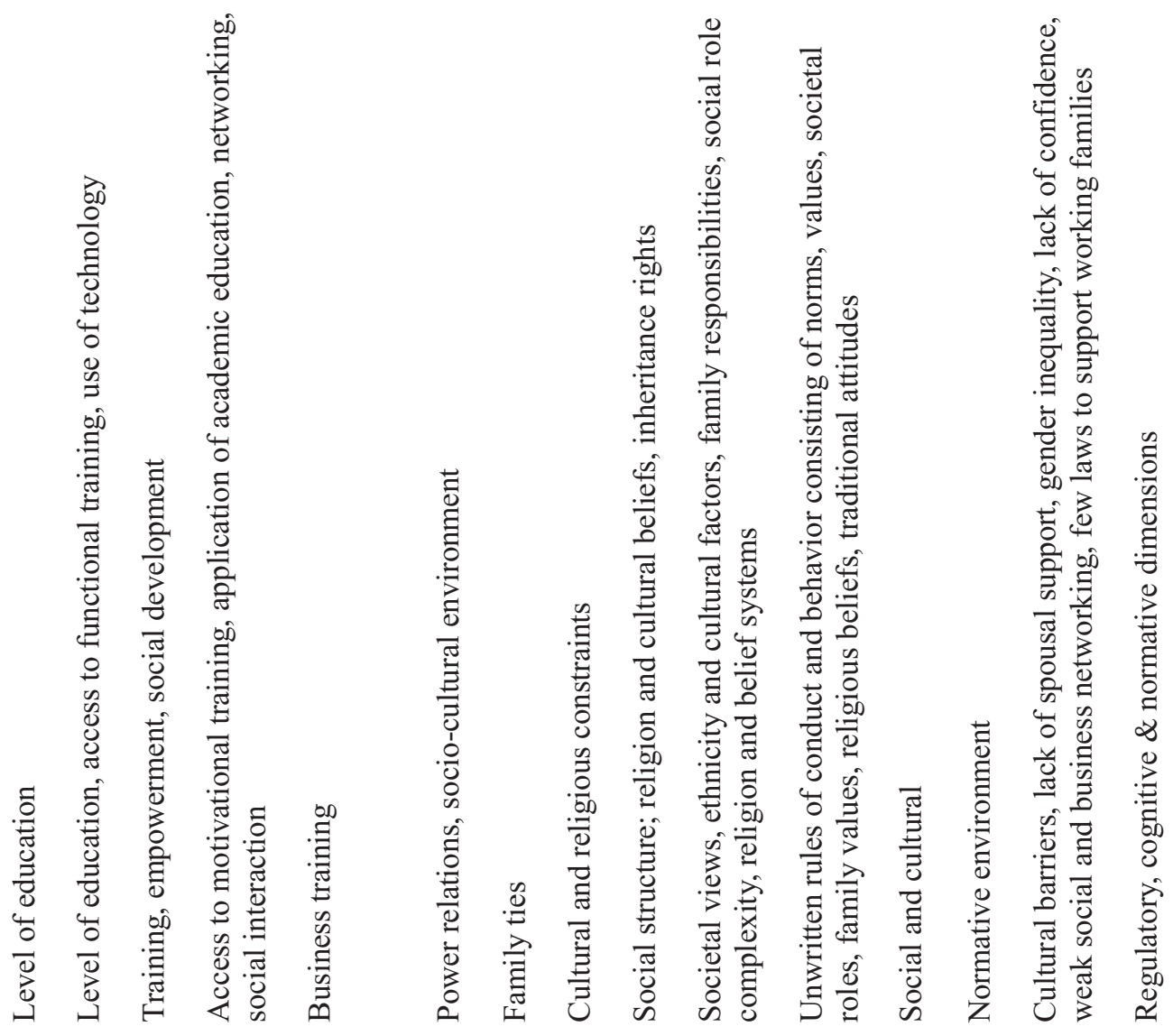

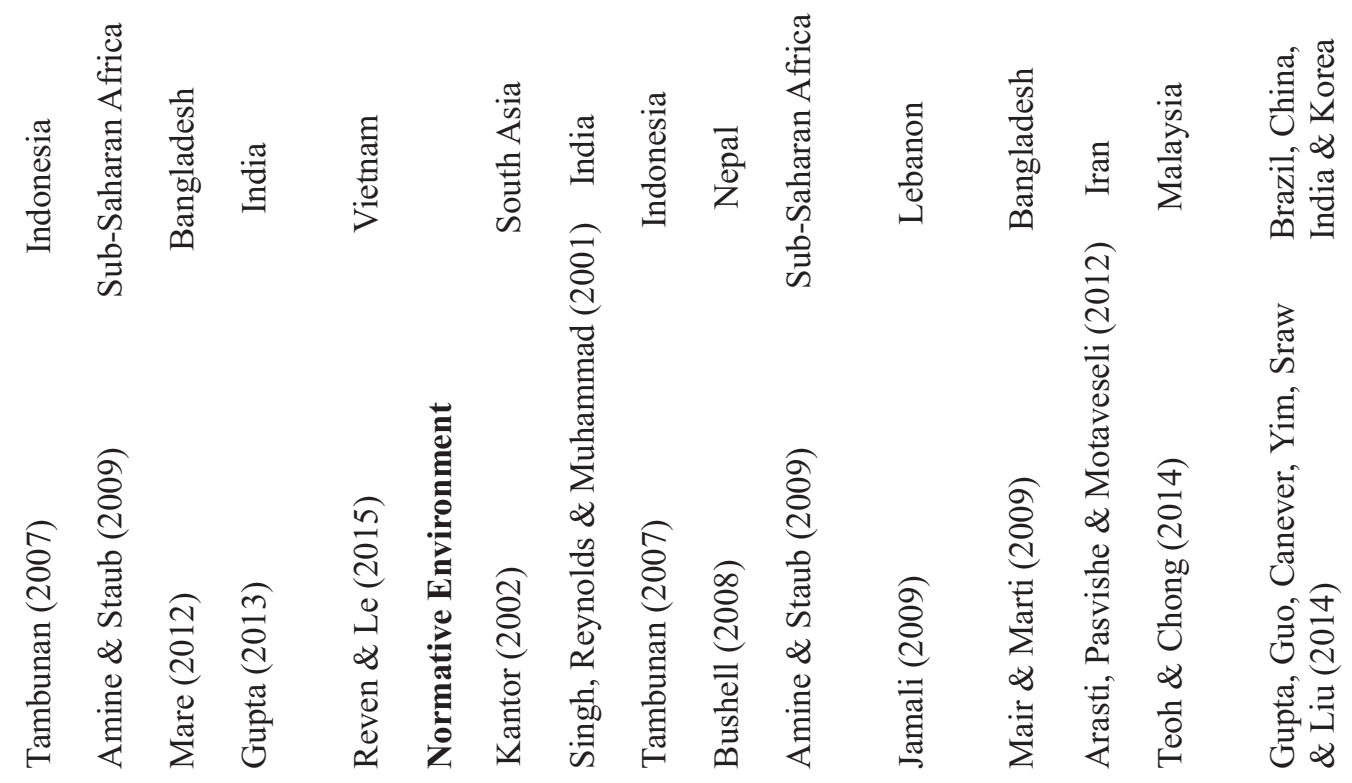




\section{Women-Led SMES and Institutional Environment in the Asia}

Review in the previous section revealed the institutions those affect SMEs in developing economies, irrespective of the gender of the business owner. However, the impact of institutional environment on the women-led SMEs has been significant (Amine \& Staub, 2009; Estrin \& Mickiewicz, 2011). Thus, from the view of the three dimensions of the institutional environment, and in line with the indications given in the above review, the following part of the paper examines how regulatory, cognitive and normative dimensions of the institutional environment affect women-led SMEs in the Asian region.

\section{Effects of Regulatory Environment}

The regulatory environment of a country may encourage or restrict the formation of new ventures, impede or expedite the growth, ensure or threaten the survival of SMEs (Busenitz et al. 2000; Thai \& Turkina, 2014). Even though macro environmental level restraints such as political instability of the country, poor infrastructure, high production costs, and non-conducive business environment' seem to affect all entrepreneurs equally, it has been found that they tend to impact more on businesswomen than businessmen (Stevenson \& St-Onge, 2005, p. 3). The Asian scenario shows multiple effects of regulatory environment on women-led SMEs.

The summary literature provided in Table 2 proved some important characteristics of the regulatory environment of developing economies. Thus, the state sector of developing countries tends to remain under-developed. Consequently, rigid rules, unsupportive bureaucratic procedures, complex regulations, old laws, undeveloped infrastructure, and unfair competition (Amine \& Staub, 2009; Smallbone \& Welter, 2011; Stevenson \& St-Onge, 2005; Tambunan, 2008; Wijesinha, 2004; Zhu, Wittman \& Peng, 2012) badly affect start-up efforts as well as survival strategies of SMEs in these countries. This knowledge shed light on the effects of regulatory environment on women-led SMEs in the Asian region.

Previous studies have emphasized that unsupportive financial regulations hinder the possibility of women's easy access to public finance, venture capital, and bank credits (IFC, 2011). Balasubramanian (2012), in an intra-household bargaining model used for South Asia, shows that microcredit leaves women worse off while benefiting men. Thus, responsive policies by financial institutions are important determinants of the growth of women entrepreneurs (Hassan \& Mugambi, 2013). Especially with womenled SMEs, this has been a critical issue due to lack of collaterals when applying for 
loans from financial institutions. Attygalle, Hirimuthugodage, Madurawala, Senaratne, Wijesinha and Edirisinghe, (2014) reporting findings of a study conducted in Sri Lanka, state that the support received from financial institutions by women SME owners are not satisfactory, and further, that they faced difficulties in obtaining loans due to banks demand on securities and company registration details.

Complex regulations have been an obstacle for women business owners due to their lack of experience in dealing with them. Most of the rural-based women SME owners do not possess adequate education to deal with complicated documentation procedures. Existing labor legislations too have been restrictive, especially in the replacement and rewarding aspects, thus discouraging further expansions of the business. Further, enterprise establishment approval, registration, and even bankruptcy proceedings are too complicated, time-consuming and expensive especially in under-developed institutional environments (Gupta et al., 2014). Thus,complexity in documentation due to institutionalized bureaucratic procedures is a huge hurdle faced by women entrepreneurs, which has created an entry barrier to SMEs led by women. Opening and closing of enterprises and shifting from one to another have been seen frequently among Asian women-led SMEs (Singh, Reynolds, $\&$ Muhammad, 2001). These instances need adherence to regulatory requirements, which has to be supported by the institutional environment (Debroux, 2013).

Zhu, Wittman, and Peng (2012), examining how institution-based barriers affect innovations of SMEs revealed the inability to cope with complex regulations, poor enforcement of unfair competition law, and regional protectionism have been the challenges in the Chinese context.

While highlighting the institutional barriers activated on women entrepreneurs, Setty and Moorthy (2010) listed (a) vague and unrealistic policies, and policies not supported by action, and (b) overlapping and duplication of functions, both at the apex and operational levels. Other than these, the regulatory aspect affecting women-led SMEs has been looked into from the part of the operationalization by the government and other agencies. Unsupportive policy environment in Sri Lanka has been an obstacle for women's business (Attygalle et al., 2014). Thereby, lack of inter-agency coordination, lack of teamwork and internal coordination in the agencies, bureaucratic style of working, and a multiplicity of agencies performing a more or less similar task have been apparent through research into women-led SMEs (Setty \& Moorthy, 2010, p.102). 
Competition at the ground level is a challenge faced by women entrepreneurs in developing contexts. Competition arises from new entrants and/or subsidiaries of large companies (Debroux, 2013). However, the institutional protection for womenled SMEs against competition, or especially, unfair competition (Zhu et al, 2012) in developing economies is minimal. Similarly, lack of development policies for regional products can be seen as another contributory factor to this effect.

Women-led enterprises in developing economies in Asia have been challenged by a lack of regulations to protect SMEs. Liu, Yang, and Zang (2012) pointed out that legal and regulatory protection may influence the benefits and costs of family business. Unclear regulations and/or lack of regulations to protect women-led SMEs are obvious facts in the Asian context. Previous researchers have repetitively underlined the unavailability of sufficient and efficient support systems for women entrepreneurs (e.g., Debroux, 2013; Gupta, 2013; Zhu et al, 2012; Wees \& Romijn, 1995). This fact can be taken up in light of insufficient and inefficient regulations for strengthening women-led SMEs in developing economies. Further, the tax burden is been highlighted as a common impediment on rural SME development (irrespective of gender). Thus, what is evident is the lack of institutional backing for economic prosperity for SMEs, which may demotivate women-SME holders.

\section{Effects of Cognitive Environment}

SMEs operating in a particular economy experience a set of practices, knowledge base and a set of skills that have been institutionalized as needed for forming and smooth functioning of them. Previous literature suggests that education and training are the basic institutions through which entrepreneurial knowledge and skills can be upgraded in a country. Accordingly, academic education (Gupta, 2013), technical assistance (Kelly, Brush, Green \& Litovsky, 2002), trainingprograms (including business training), socialization programs (promoting networking) (Mare, 2012; Raven \& le, 2015) have been noted as the institutions affecting in SMEs in developing countries. This background knowledge eases understanding the effect of cognitive dimension on women-led SMEs in the Asian region.

A plenty of existing literature has identified education, prior work experience, networking opportunities, and/or communication skills as critical factors for startingup of a business or successful performance of women entrepreneurs (Bennett \& Dann, 2000; Ekepy, Razak \& Mat, 2013; Yusuf, 1995). Williams and K'nIfe (2012) find when compared to male-owned firms, female-owned firms have principals that are less 
educated, have less work experience, the firm size is much smaller, the firms are much younger, the firms are more likely to be organized as proprietorship or partnership, and they are less likely to borrow from a bank.

Debroux (2013), compiling evidence on Asian women entrepreneurs, reveals the exclusion of women from formal education in Malaysian and Vietnamese contexts. Birley (1989), citing El- Namaki and Gerritson, reminds the vicious cycle of barriers for women those stepping into entrepreneurship. This cycle passes the stages of 'secondary position of women in the society', leading to 'little or no education', thus realizing 'no work in the formal sector', and leading to 'engaging in the informal sector' and thus proceeding with ;no improvements in the life conditions", and making their daughters flowing to the same cycle by 'pushing them to household work'. It puts together several facets that deal with practices, knowledge, and skills of women that needed for business in developing economies in the Asia such as the lack of education opportunities, lack of chances for obtaining formal work experience, lack of networking opportunities, and lack of training in the business or external world. Bhardwaj (2014), studying the case of Indian women entrepreneurs, indicates that having access to appropriate education enables them finding sources of innovative ideas and thus converting these ideas into practice in their enterprises. He also reveals that time and resource unavailability for women entrepreneurs have led them to difficulties in training and equipping themselves in line with the recent developments in technology and the market.

Networking is a determinant of performance of women-owned business (Omwenga, Mukulu \& Kanali, 2013). Lack of networking opportunities leads to lack of information, which is an imperative for entrepreneurial success. Access to information sources eases getting into new market opportunities, constant vigilance on new offerings, development of professional relationships, and acquiring managerial experiences through networking. However, women entrepreneurs seem to be challenged in this aspect due to their low position in education, experience, and training (Sing, Reynolds \& Muhammad, 2001). Typically, information networks strengthen relationships with diverse stakeholders around the business, thus leading to ensuring trusted support from each. This lack of opportunity seems to be a huge challenge encountered by women-led SMEs in the Asian region.

Lack of vocational training opportunities for women has impeded women entrepreneurs' involvement in public spaces (Mare, 2012). Highlighting the case of Bangladesh, Mare (2012) spells out the impasse on women-led SMEs' mobility 
towards urban areas or even to international arenas occurred due to lack of training, empowerment, and their social development. Gupta (2013), revealing the case of India, emphasizes the restrictions operated against women entrepreneurs on their access to training, and thus stresses on the need of specific skill development programs focusing on motivation factor, pulling factors and pushing factors inwomen's entrepreneurship. He further weights on the need of developing social interaction, networking skills, practical application of academic education and motivational training for girls and women, which seem to be challenging for women-led SMEs. Orser, Telfer and Findlay- Thompson (2012) highlighted the need for women-focused small business training centers. Raven and Le (2015), taking up a Vietnamese case, highlights the impact of business training on women microentrepreneurs.

The contemporary business society evidences to the need of applying more information and communication technology (ICT) in the business. However, Asian women are still away from ICT education when compared to their male counterparts. This vacuum in knowledge has become an impediment to the growth of women-led SMEs (Debroux, 2013) as it inhibits information flows on markets, thus decreasing the degree of marketing power.

\section{Effects of Normative Environment}

The previous research findings imply that the socio-cultural environment of a country at large (including religious beliefs and ethnic diversities) predominantly forms the normative aspect of the institutional environment. Thus, the effects of the normative environment are created mainly by social institutions which derive through the human interactions and consequent social constructions of a set of norms, values, beliefs, customs, traditions, expectations and assumptions of its people (Arasthi, Pasvishe \& Motavaseli, 2012; Cooper, 1981). Such social institutions result in social structure, power relations, gender role expectations, and occupational segregations, and impose certain effects on entrepreneurship, especially in developing contexts (Birley, 1989; Kantor, 2002; Wees \& Romijn, 1995). Socialization plays a pivotal role in hindering or facilitating entrepreneurial efforts. Schapero and Sokol's (1982) model explicated how entrepreneurial event formation is backed by the socio-cultural environment (perceptions of desirability) of micro and small enterprises. They stressed the influences of primary social connections such as family, peer group and ethnic group in entrepreneurial decision making. This background knowledge enlightens the understanding effects of normative dimension on women-led SMEs in the Asian region. 
World Bank (2014) reports that 'societal level attitudes are important for entrepreneurs' (p.10). Societal attitudes prevailing in the Asian countries have proven to be affecting business women (e.g., Kantor, 2002; World Bank, 2011). Women's entering into business has been seen by the general society different to that of men's (Birley, 1989). Hereby, the role of national culture, acceptable norms of behavior by women entrepreneurs, traditional family relationships (Birley, 1989) are vital in forming the social attitudes towards women-led SMEs. Asian context is profoundly debated on its traditional family systems, conservative thinking, Confucian ethics, extended families and elder decision making. Accordingly, women-led SMEs in Asia encounter more challenges in its normative setting in the institutional environment.

Formation of an enterprise by women becomes a challenge in Asia due to many reasons. The broad-based thinking that, "women are not serious in business" and "women are not credible in business operations" (Wees \& Romijn, 1995) are still prevailing in the Asian society. Further, in line with the deeply internalized social role of women as wives and mothers, there is a tendency that women-led SMEs are seen as 'unusual'. In certain instances, resistance and reservations are accrued from elderly women in the family, when rural women step into forming their own businesses (Wees \& Romijn, 1995). Wees and Romijn continue with the fact that daughters and daughter-in-laws in families are not usually allowed to take up a business as a successor, but instead a son or a son-in-law.

Sadik (1997) states that South Asian women suffer a low social status where their basic needs and fundamental rights have been denied. Even in continuing with an existing enterprise, women find difficulties in the face of male-dominated business environment due to low recognition and low esteem granted by the general society. Strong business segregation, particularly based on the occupational segregation based on the social norms, is also visible between men and women in the Asian context. Choy, Lee, and Ramburuth (2008) found that individual work values differ among men and women in Southeast Asia. Wees and Romijn (1995) maintain that women undergo discrimination, resistance, and greater constraints when they step into maledominated business sectors. Thus, most economically productive business sectors are due for men, while a narrow range of economically low productive sectors (e.g., weaving, spinning, food processing, producing home-based utensils etc.) are normatively assured for girls and women (Singh, Reunolds \& Muhmmad, 2001).

Household work burden due to an unequal share of family responsibilities, limited mobility, lack of maternity protection and lack of access to networks (Attygalle et al., 
2014) have restrained women in Sri Lanka and put back women business owners in Sri Lanka. Further, the invisible barrier in the form of traditional customs and domestic and social expectations hinder women's active involvement in the business (Attygalle et al., 2014). These social barriers, all together, would negatively affect women-led SMEs by making them impossible in obtaining public support and limiting external services (Zhu et al, 2012).

\section{Conceptualization}

Under-developed institutions (Welter \& Smallbone, 2011) and the institutions activated in the Asian region have negatively affected on SMEs (Gupta et al. 2014; Kelley, Brush, Greene \& Litovsky, 2011; Mare \& Marti, 2009). The present study identifies that there are certain specific characteristics pertaining to women-led SMEs in the Asia. Thus, seemingly, with less support from the regulatory environment, lack of sufficient inputs from the cognitive environment and experienced constraints from the normative environment, the women-led SMEs in the Asia tend to locate in the rural traditional (Senguptha, Datta \& Momdal, 2013). Weekly Insights and Analysis in Asia (2013), notes that women's entrepreneurial involvement in Asia is gathered around the informal sector. They remain as microenterprises or small business (Bardasi, Sabarwal \& Terrell, 2011; Krishnan \& Kamalanabhan, 2013), and as home-based businesses. Their businesses are characterized by low capital requirements, low barriers to entry and exit (Singh, Reynolds \& Muhammad, 2001), low income generating and largely based in the service sector (Female Entrepreneurship Resource Point, 2012). Due to lack of capital investments, credit facilities, property rights, and favorable profiles, women-owned businesses in the Asian region are largely revolved around less demanding, slow growing, and less value adding segments of the economy (IFC, 2011; World Bank, 2012). Re-investments in the women-owned business have been restricted not only due to their slow growth potential but due to their household financial responsibilities (Mahmood, 2011).

Low business performance of women entrepreneurs in the Asia have been noted in the previous studies (Bardasi, Sabarwal \& Terrell, 2011; GEM, 2012). Alsos, Isaksen and Ljunggren (2006) finds that the lower levels of financial capital that women business founders achieve areassociated with lower early business growth compared with their male counterparts. D'espallier, Guerin, and Mersland, (2012) find that women's loan repayment has been improved, however, their overall performance has remained low (due to higher relative costs). 
Present study reveals the institutional environmental effects on women-led SMEs in terms of regulatory, normative and cognitive dimensions. What unveils in the study is summarized in the following figure.

\section{Conclusion and Implications}

Adapting the institution-based view and thus probing into regulatory, normative, and cognitive dimensions of the institutional environment, this research examined the

Figure 1: Institutional Effects on Women-led SMEs

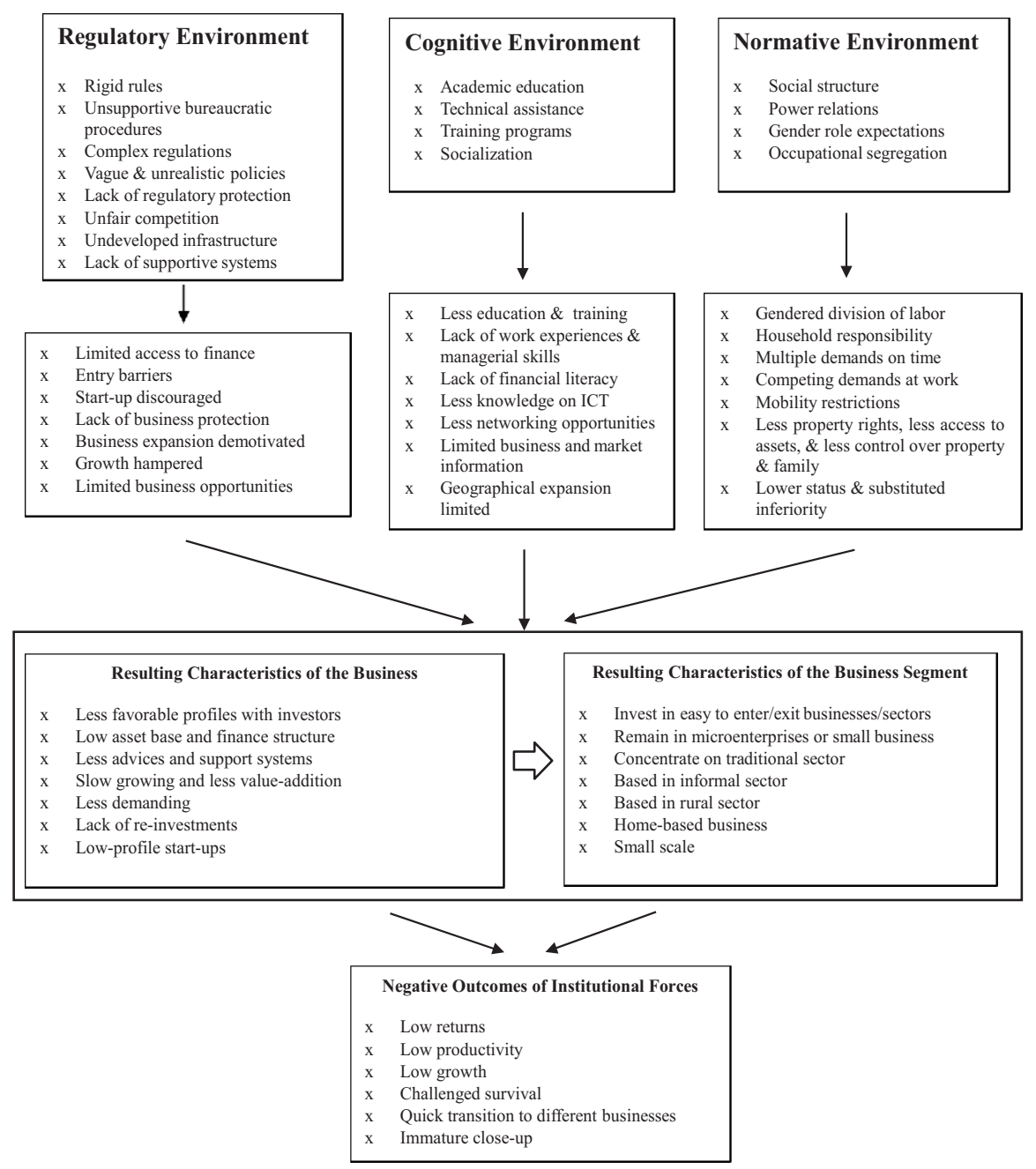

effects of institutional environment on women-led SMEs in the Asia. It unveils a macro-level picture of the aforesaid three dimensions enabling the policy makers and decision makers to draw appropriate insights for necessary actions. It further contributes to the theorists and researchers a framework for further investigations. 
The major implications are drawn below on three forces: regulatory, normative, and cognitive, respectively.

\section{Regulatoryforces}

Even though one may argue that the effects of the regulatory environment are common for both men and women in SMEs, this study contends the need of having a special concern on women- led SMEs, when they contribute to the economy in substantial and sizable figures. Thereby, positive discrimination (Debroux, 2013) would be needed in formulating certain protective policies for women-led SMEs. Especially in the Asian context, the need of protective mechanisms for women-led SMEs would be a must amid unfair competition accrues from large firms, subsidiaries of large firms, newly entering powerful male-owned enterprises, and trade intermediaries. Further, development policies for regional products would help protection of home-based, rural-based, region-based women-led SMEs. Government intervention for developing the institutional environments especially in developing economies has to be stressed, as under-developed institutional environments (Liu, Yang \& Zhang, 2012) create ambiguities and complexities for minority groups with less formal education in the society. Thus, elimination of bureaucratic procedures, simplification of documentation, and avoiding duplication in processes will be in the focus when considering the establishment approval, business registration, change of business etc. of SMEs.

\section{Cognitive forces}

The cognitive pillar of the institutional environment suggests the need for upgrading the level of formal education, skill level (including communication and networking skills), and knowledge on ICT of women entrepreneurs. Thus, diversified skill development programs, networking opportunities, motivational training, and vocational training (Gupta, 2012; Mare, 2012) at rural areas would help immensely. Further, establishing information systems for the use of women entrepreneurs, expert support systems, and a system of intermediaries to attend immediately to the consulting needs of women SME holders are suggestible.

\section{Normative forces}

In the normative domain, the institutional environment has to take positive measures for uplifting women-led SMEs, especially through impression building. Thus, 
highlighting women role models who have succeeded in the business, and opening up dialogues for publicizing their success stories have to be taken up at the general society level. Storytelling or narrative mechanisms may help eliminate traditional and conservative normative thinking grounded in the general society, which is destructive for contemporary women-led SMEs.

\section{Limitations and Directions for Further Research}

Present study identifies the effects of the three dimensions of the local institutional environments from the currently available literature. However, an empirical study, investigating the effects of such institutions on women-led SMEs, would further enlighten us on this topic.

Being reviewed the above three dimensions, the present study contends that the actors in the institutional environment play the role of moderators which weaken (most of the cases) or strengthen the relationship between the individual (personal) characteristics and the performances of women-led SMEs. However, these are hypothetical relationships which could be elaborated in further studies. Accordingly, an empirical investigation of the role of moderators (regulatory, normative, and cognitive environments) is suggested in this study.

SMEs, as any other organizations, surpass different life cycle stages (Quinn \& Cameron, 1983) throughout their survival up to decline. Formation, growth, maturity, and decline stages of women-led SMEs may undergo multiple challenges, thus, reminding us the possibility of institutional environment affecting them differently at different life cycle stages. However, the present study has not considered of the life cycle stages of the women-led SMEs, in this conceptualization. An investigation of the impact of institutional environment on women-led SMEs at their diverse life cycle stages would enable policy makers and decision makers grasp a more comprehensive picture of the reality of such enterprises.

\section{References}

Aidis, R., Estrin, S., \& Mickiewicz, T. (2012). Size matters: Entrepreneurial entry and government. Small Business Economics, 39(1), 119-139. doi:10.1007/s11187010-9299-y. 
Alsos, G.A., Isaksen, E.J. \& Ljunggren, E. (2006). New Venture Financing and Subsequent Business Growth in Men- and Women-Led Businesses. Entrepreneurship Theory and Practice, 30(5), 667-686.

Amine, L. S., \& Staub, K. M. (2009). Women entrepreneurs in sub-Saharan Africa: An institutional theory analysis from a social marketing point of view. Entrepreneurship \& Regional Development: An International Journal, 21(2), 183-211. DOI: $10.1080 / 08985620802182144$

Arasti, Z., Pasvishe, F. A., \& Motavaseli, M. (2012). Normative Institutional Factors Affecting Entrepreneurial Intention in Iranian Information Technology Sector, Journal of Management and Strategy, 3(2), 16-24.

Attygalle, K., Hirimuthugodage, D., Madurawala, S., Senaratne, A., Wijesinha, A.\& Edirisinghe, C. (2014). Female entrepreneurship and the role of business development services in promoting small and medium women entrepreneurs in Sri Lanka. Colombo, Sri Lanka: Institute of Policy Studies (IPS) of Sri Lanka and Oxfam International.

Autio, E., \& Fu, K. (2015). Economic and political institutions and entry into formal and informal entrepreneurship. Asia Pacific Journal of Management, 32, 67-94. DOI 10.1007/s10490-014-9381-0Balasubramanian, S. (2012). Why micro-credit may leave women worse off: Non-cooperative argaining and the marriage game in South Asia. The Journal of Development Studies, 49(5), 609-623.

Bell, P. F. (1969). A quantitative study of entrepreneurship and its determinants in Asia.Canadian Journal of Economics, 2(2), 288-298.

Bennett, R., \& Dann, S. (2000). The Changing Experience of Australian Female Entrepreneurs.Gender, Work and Organization, 7(2), 75-83.

Berger, P. L., \& Luckmann, T. (1966). The social construction of reality: A treatise in the sociology of knowledge. Garden City, NY: Doubleday.

Beyer, H. \& Fening, F. (2012). The impact of formal institutions on global strategy in developed vs. emerging economies. International Journal of Business and Social Science, 3(15), 30-36.

Bhardwaj, B. R. (2014). Impact of education and training on performance of women entrepreneurs. Journal of Entrepreneurship in Emerging Economies, 6(1), 38-52.

Birley, S. (1989). Female Entrepreneurs: Are they really any differentfi Journal of Small Business Management, 27(1), 32-37. 
Busenitz, L., Gomez, C., \& Spencer, J. (2000). Country institutional profiles: Unlocking entrepreneurial phenomena. Academy of Management Journal, 43(5), 994-1003.

Bushell, B. (2008). Women entrepreneurs in Nepal: what prevents them from leading the sectorfi, Gender \& Development, 16(3), 549-564, DOI: $10.1080 / 13552070802465441$

Choy, W.K.W., Lee, A.B.E., \& Ramburuth, P. (2008). Variations in values: A narrowing gap between male and female employees in a Singaporean firm in Southeast Asiafi Women's Studies,37(5),464-494. DOI: 10.1080 / 00497870802165445

Clercq, D. D., Lim, D.S.K., \& Oh, C. H. (2013). Individual-level resources and new business activity: The contingent role of institutional context. Entrepreneurship Theory \& Practice, 303-330. DOI: 10.1111/j.1540-6520.2011.00470.x

Collins, J. (2003). Cultural diversity and entrepreneurship: policy responses to immigrant entrepreneurs in Australia Entrepreneurship \& Regional Development: An International Journal, 15(2), 137-149, DOI: 10.1080/0898562032000075168

Cooper, A. C., (1981). Strategic Management: New Ventures and Small Business. Long Range Planning, 14(5), 39-45.

Davidsson, P., Hunter, E. \& Klofsten, M. (2006). Institutional Forces The Invisible Hand that Shapes Venture Ideasfi International Small Business Journal, 24(2), 115-131. DOI: $10.1177 / 0266242606061834$

Debroux, P. (2013). Female entrepreneurship in Asia - the case of Japan, South-Korea, Malaysia and Vietnam. Soka Keiei Ronshu, 37(1/2/3), 1-23.DiMaggio, P. J., \& W. W. Powell (1983). The iron cage revisited: Institutional isomorphism and collective rationality in organizational fields. American Sociological Review, 48, 147-160.

Djankov, S., R. La Porta, F. Lepez-de-Silanes, \& A. Shleifer, A. (2002). The regulation of entry.The Quarterly Journal of Economics, 117, 1-37.

Edoho, F. M. (2016), Entrepreneurship paradigm in the new millennium. Journal of Entrepreneurship in Emerging Economies, 8(2), 279-294.

Ekpe, I., Razak, R.C., \& Mat, N.B. (2013). The performance of female entrepreneurs: Credit, training and the moderating effect of attitude towards risk-taking. International Journal of Management, 30(3), 10-22. 
Eroğlu, S. E. (2012). Values: Great challenge for construction of social structure with social institutions. International Journal of Human Sciences, 9(2), 82-90.

Estrin, S., \& Mickiewicz, T. (2011). Institutions and female entrepreneurship, Small Business Economics, 37, 397-415.

Female Entrepreneurs Resource Point (FERP), (n.d.). Retrieved on 14 May 2015 through FemaleEntrepreneurshipResourcePoint041113

Global Entrepreneurship Monitor (GEM), (2013). Global Entrepreneurship Monitor Women's Report 2012. Retrieved on 20 May 2014 from www.gemconsortium.org

Gupta, D.D. (2013). The effect of gender on women-led small enterprises: The case of India. South Asian Journal of Business Management and Cases, 2(1), 61-75.

Gupta, V. K., Guo, C., Canever, M., Yim, H. R., Sraw, G. K., \& Liu, M. (2014). Institutional environment for entrepreneurship in rapidly emerging major economies: the case of Brazil, China, India, and Korea. International Entrepreneurship Management Journal, 10, 367- 384. DOI 10.1007/s11365012-0221-8

Hassan, I. B. \& Mugambi, F. (2013). Determinants of growth for women owned and operated micro enterprises: The case of Garissa, Kenya. International Journal of Business and Commerce, 2(7), 45-55.

International Finance Corporation. (2011). Strengthening access to finance for women-owned SMEs in developing countries. Retrieved from http://www.ifc.org/wps/wcm/connect/a4774a004a3f66539f0f9f8969adcc27/G2 0_Women_Report. pdffiMOD=AJPERES on 20 June 2014.

International Center for Research on Women (ICRW), (2010). Bridging the gender divide: How technology can advance women economically. (Author).

Jamali, D. (2009). Constraints and opportunities facing women entrepreneurs in developing countries: A relational perspective. Gender in Management: An International Journal, 24(4), 232-251. doi.org/10.1108/17542410910961532

Jayawarna, D., \& Jones, O. (2014). Entrepreneurial potential: The role of human and cultural capitals. International Small Business Journal, 32(8), 918-943.

Kantor, P (2002). Gender, micro enterprise and cultural context: The case of South Asia. Entrepreneurship Theory \& Practice, 131-143.

Katre, A., \& Salipante, P. (2012). Start-up social ventures: Blending fine-grained ehaviors From two institutions for entrepreneurial success. Entrepreneurship Theory \& Practice, 967-994. 
Kelley, D. J., Brush, C. G., Greene, P.G., \& Litovsky, Y. (2011). Global entrepreneurship monitor 2010 report: Women entrepreneurs worldwide. Retrieved from www.gemconsortium.org on 20 June, 2014.

Kolvereid, L., Shane, S., \& Westhead, P. (1993). Is it equally difficult for female entrepreneurs to start businesses in all countriesfi Journal of Small Business Management, 42-51.

Krishnan, L., \& Kamalanabhan, T.J. (2013). Entrepreneurial success and life satisfaction among women entrepreneurs in micro enterprises. South Asian Journal of Management, 20(2), 40-63.

Kyrö, P. (2009). Gender lenses identify different waves and ways of understanding women entrepreneurship, Journal of Enterprising Culture, 17(4), 393-418.

Lee, S.S., \& Stearns, T.M. (2012). Critical success factors in the performance of female owned businesses: A study of female entrepreneurs in Korea. International Journal of Management, 29(1), 3-18.

Liu, W., Yang, H. \& Zang, G. (2012). Does family business excel in firm performancefi An institution-based view. Asia Pacific Journal of Management, $29,965-987$

Mahmood, S. (2011). Microfinance and women entrepreneurs in Pakistan, International Journal of Gender and Entrepreneurship, 3(3), 265-274.

Mair, J. \& Marti, I. (2009). Entrepreneurship in and around institutional voids: A case study from Bangladesh. Journal of Business Venturing, 24, 419-435.

Manolova, T.S., Eunni, R.V., \& Gyoshev, B.S. (2008). Institutional environments for entrepreneurship: Evidence from emerging economies in Eastern Europe. Entrepreneurship Theory and Practice, 32(1), 203-218.

Mare, A.L. (2012). Show the world to women and they can do it: Southern Fair Trade Enterprises as agents of empowerment. Gender \& Development, 20(1), 95-109.

Morgan, G. (1998). Images of Organization. California: Sage.

Muntean, S. C. (2013). Wind beneath my wings: Policies promoting high-growth oriented women entrepreneurs. International Journal of Gender and Entrepreneurship, 5(1), 36-59.

North, D.C. (1990). Institutions, institutional change and economic performance. Cambridge: Harvard University Press.North, D.C. (1991). Institutions. The Journal of Economic Perspectives, 5(1), 97-112. 
Omwenga, J.Q., Mukulu, E., \& Kanali, C. (2013). Business networking and performance of women-led enterprises: An empirical investigation in Nairobi county, Kenya. International Journal of Sciences: Basic and Applied Research, 11(1). 10-17.

Orser, B., Telfer, C. E., \& Findlay-Thompson, S. (2012). Women-focused small business programming: Client motives and perspectives. International Journal of Gender and Entrepreneurship, 4(3), 236-265.

Powell, B. (2007). The environment of productive entrepreneurship. Indian Journal of Economics \& Business, (Special Issue), 79-92.

Parboteeah, K. P, Hoegl, M., \& Cullen, J. B. (2008). Managers' gender role Attitudes: A country institutional profile approach. Journal of International Business Studies, 39(5), 795-813.

Quinn, R., \& Cameron, K. (1983). Organizational life cycles and shifting criteria of effectiveness: some preliminary evidence. Management Science, 29, 33-51.

Raven, P., \& Le, Q. V. (2015). Teaching business skills to women. International Journal of Entrepreneurial Behavior \& Research, 21(4), 622-641.

Redding, S. (1986). Entrepreneurship in Asia. Euro-Asia Business Review, 5(4), 23-27.

Roxas, B., \& Coetzer, A. (2012). Institutional environment, managerial attitudes and environmental sustainability orientation of small firms. Journal of Business Ethics, 111, 461-476.

Sadik, N. (1997). Women, population and sustainable development in South Asia. Journal of International Affairs, 51(1), 147-168.

Schapero, A., \& Sokol, L. (1982). The social dimensions of entrepreneurship. In K. Vesper, D. Sexton, and C.A. Kent (eds.), Encyclopedia of Entrepreneurship, Englewood Cliffs, NJ: Prentice-Hall.

Scott, W. R. (1995). Institutions and organizations. Thousand Oaks: Sage.

Setty, E.D. \& Moorthy, P.K. (2010). Strategies for developing women entrepreneurs. New Delhi: Akansha Publishing House.

Singh, S. P., Reynolds, R.G., \& Muhammad, S. (2001). A gender-based performance analysis of micro and small enterprises in Java, Indonesia. Journal of Small Business Management, 39(2), 174-182.

Sinha, P. (2003). Women Entrepreneurship in the North East India: Motivation, Social Support and Constraints. Indian Journal of Industrial Relations, 38(4), 425-443. 
Smallbone D. \& Welter, F. (2001). The Distinctiveness of Entrepreneurship in Transition Economies. Small Business Economics, 16(4), 249-262.Ssewamala, F. M., \& Sherraden, M. (2004). Integrating saving into microenterprise programs for the poor: Do institutions matterfiSocial Service Review, 78(3), 404-429.

Steensma, H.K., Marino, L., Weaver, K. M. \& Dickson, P. H. (2000). The influence of national culture on the formation of technology alliances by entrepreneurial firms. Academy of Management Journal, 43(5), 951-973.

Stevenson, L., \& St-Onge, A. (2005). Support for Growth-oriented Women Entrepreneurs in Ethiopia, Kenya and Tanzania: An Overview Report, Geneva: ILO.

Tambunan, T. (2007). Development of SME and women entrepreneurs in a developing country: The Indonesian story. Small Enterprise Research, 15(2), 31-51.

Tambunan, T. (2008). SME development, economic growth, and government intervention in a developing country: The Indonesian story. Journal of International Entrepreneurship, 6, 147-167. DOI 10.1007/s10843-008-0025-7

Tang, Z. \& Tang, J. (2012). Entrepreneurial orientation and SME performance in China's changing environment: The moderating effects of strategies. Asia Pacific Journal of Management, 29, 409-431.

Thai, M.T.T. \& Turkina, E. (2014). Macro-level determinants of formal entrepreneurship versus informal entrepreneurship. Journal of Business Venturing, 29, 490-510.

UNWOMEN (official web page). Retrieved on 24th May 2014 through http://www.unwomen.org/en/where-we-are/asia-and-the-pacific

Urban, B. (2013). Social entrepreneurship in an emerging economy: A focus on the institutional environment and social entrepreneurial self-efficacy. Managing Global Transitions, 11(1), 3-25.

Weekly Insights and Analysis in Asia (2013). Networking essential to women entrepreneurs in Asia. The Asia Foundation. Retrieved on 24th May 2014 through asiafoundation.org/in- asia/2013/02/27/networking-essential-to-womenentrepreneurs-in-asia/

Wees, C.V.D. \& Romijn, H. (1995). Entrepreneurship and small- and microenterprise development for women: A problematic in search of answers, a policy in search of programs. In L. Dignard and J. Havet (eds.), Women in micro- and small-scale enterprise development, London: IT Publications, 41-82. 
Welter, F., \& Smallbone, D. (2011). Institutional perspective on entrepreneurial behavior in challenging environments. Journal of Small Business Management, 49(1), 107-125.

Wickremasinghe, S.I. (2011). The status of SMEs in Sri Lanka and promotion of their innovation output through networking of S\&T institutions, TECH Monitor, Special Issue: Institutional Networking for Enhancing Innovation, 1119.

Wijesinghe, R. T. (2004). Unleashing Entrepreneurship: Making Business Work for the Poor. Presentation on Conducive Policy, Legal and Institutional Framework that helps tostrengthen foundations for the development of the Private Sector with special focus on SMEs, UNDP Press Release No. 289, New Delhi, 15 December 2004.

Williams, D. A., \& K'nIfe, K.A.K. (2012). Correlates of gender and credit behavior in small firms: Evidence from a small, developing economy. Entrepreneurial Executive, 17, 69-85.

World Bank. (2011). Ease of doing business. Retrieved January 18, 2011, from http://www.doingbusiness.org/data/exploreeconomies/germany

World Bank Report 2011 (2012). Gender equality and development. World Bank, (Author).

World Bank. (2014). Gender and Development, Retrieved on 27 June 2014 from http://web.worldbank.org/website/external/topics/extgender/0

Yusuf, A. (1995). Critical success factors for small business: Perceptions of South Pacific entrepreneurs. Journal of Small Business Management, 33(2), 68-73.

Zhu, Y., Wittmann, X., \& Peng, M.K. (2012). Institution-based barriers to innovation in SMEs in China. Asia Pacific Journal of Management, 29, 1131-1142. 